\title{
Analisis sifat fisika pemanfaatan pati tandan kosong sawit dan limbah plastik LDPE sebagai bahan pembuatan plastik biodegradabel
}

\section{Physical properties analysis of the utilization of starch from palm empty fruit bunch and LDPE plastic waste as biodegradable plastic materials}

\author{
Tengku Rachmi Hidayani*, Elda Pelita, Gusfiyesi \\ Politeknik ATI Padang, Jalan Bungo Pasang Tabing Padang 25171, Indonesia. \\ * Penulis korespondensi. Telp. +62751 7055053, Fax. +62751 41152 \\ E-mail: rachmihidayani@yahoo.com
}

Diterima: 25 Januari 2017 Direvisi: 7 Mei $2017 \quad$ Disetujui: 9 Mei 2017

\begin{abstract}
This research aimed to overcome the issue of plastic packaging waste that accumulates in nature because synthetic polymers cannot be easily unraveled by bacteria. Biodegradable plastics were produced by mixing waste of plastics of the low density polyethylene (LDPE) with starch of empty palm fruit bunches, modified with the addition of maleic anhydride as a crosslinking agent. To produce biodegradable plastics, different compositions of LDPE waste, starch of empty palm fruit bunch, maleic anhydride, and benzoyl peroxide were used, namely (90: 10:1:1), (80:20:1:1), (70:30:1:1), and (60:40:1:1). Research stages consisted of extraction of starch from palm empty fruit bunch (PEFB); preparation of biodegradable plastic powder with the reflux method and xylene solvents; and making of biodegradable plastics using the press molding method. Based on the results of characterization, it was revealed that the optimum condition was generated by biodegradable plastics with the composition of LDPE waste, starch of empty palm bunches, maleic anhydride, and benzoyl peroxide was equal to 60: 40: 1: 1, which generated the tensile strength value of $6.9410 \mathrm{~N} / \mathrm{m}^{2}$, the elongation at break of $3.1875 \%$, the the melting point temperature of $103^{\circ} \mathrm{C}$, and the decomposition temperature of $384^{\circ} \mathrm{C}$. Besides, the thermal gravimetric test generated a residue of $12.6 \%$ and results of the analysis on morphological properties suggested that the starch distributed evenly.
\end{abstract}

Keywords: biodegradable plastics, LDPE waste, LDPE-g-MA, starch, palm empty fruit bunch.

\begin{abstract}
ABSTRAK
Penelitian ini bertujuan untuk mengatasi limbah plastik kemasan yang menumpuk di alam karena polimer sintetis yang sulit diuraikan oleh bakteri. Plastik biodegradabel dibuat dengan mencampur limbah plastik polietilena jenis Low Density Polyetylene (LDPE) dengan pati tandan kosong sawit (TKS), dimodifikasi dengan menambahkan maleat anhidrida sebagai agen pengikat silang. Untuk menghasilkan plastik biodegradabel dilakukan variasi perbandingan tertentu antara limbah LDPE, pati TKS, maleat anhidrida dan benzoil peroksida (90:10:1:1), $(80: 20: 1: 1),(70: 30: 1: 1)$, dan (60:40:1:1). Tahapan penelitian ini yaitu ekstraksi pati dari TKS, preparasi serbuk plastik biodegradabel dengan metode refluks menggunakan pelarut xilena dari berbagai variasi komposisi limbah LDPE, pati TKS, maleat anhidrida, dan benzoil peroksida, pencetakan plastik biodegradabel dengan metode kempa tekan. Dari hasil karakterisasi dapat diperoleh kondisi optimum yang dihasilkan plastik biodegradabel dengan perbandingan limbah LDPE, pati TKS, maleat anhidrida, benzoil peroksida (60:40:1:1) yang memiliki harga kuat tarik $6,9410 \mathrm{~N} / \mathrm{m}^{2}$ dan nilai kemuluran $3,1875 \%$, suhu titik lebur $103^{\circ} \mathrm{C}$ dan suhu terdekomposisi $384^{\circ} \mathrm{C}$, pada uji termal gravimetri didapatkan residu $12,6 \%$, dan analisis sifat morfologi menunjukan sebaran pati TKS merata.
\end{abstract}

Kata kunci: plastik biodegradabel, limbah LDPE, LDPE-g-MA, pati, tandan kosong sawit. 


\section{PENDAHULUAN}

Plastik biodegradabel adalah suatu material polimer yang berubah menjadi senyawa berat molekul yang lebih rendah dengan sedikitnya satu tahap pada proses degradasinya melalui metabolisme organisme secara alami (Astawan, 2008). Plastik biodegradabel berbahan dasar pati/amilum dapat didegradasi oleh bakteri pseudomonas dan bacillus yang memutus rantai polimer menjadi monomer-monomernya. Senyawa-senyawa hasil degradasi polimer selain menghasilkan karbon dioksida dan air, juga menghasilkan senyawa organik lain yaitu asam organik dan aldehida yang tidak berbahaya bagi lingkungan (Khoramnejadian et al., 2013).

Plastik berbahan dasar pati/amilum aman bagi lingkungan. Sebagai perbandingan, plastik tradisional membutuhkan waktu sekitar 50 tahun agar dapat terdekomposisi alam, sementara plastik biodegradable dapat terdekomposisi 10 hingga 20 kali lebih cepat. Hasil degradasi plastik ini dapat digunakan sebagai makanan hewan ternak atau sebagai pupuk kompos (Matondang, 2013).

Pati merupakan polimer alami yang bersifat biodegradabel. Dengan menambahkan pati ke dalam polimer sintesis maka diharapkan plastik yang dihasilkan dapat terdegradasi secara alami. Plastik biodegradabel berbahan dasar pati dapat didegradasi oleh bakteri dengan cara memutus rantai polimer menjadi monomer-monomernya (Inggaweni, 2015).

Penelitian mengenai pencampuran low density polyethylene (LDPE) dengan pati ubi dengan penambahan asam akrilat telah dilakukan oleh Susilawati et al. (2011). Kondisi optimum didapatkan pada perbandingan LDPE dan pati $6: 4$ dengan kekuatan tarik $0,38 \mathrm{kgf} / \mathrm{mm}^{2}$, namun memiliki ikatan kimia yang lemah. Ikatan kimia yang lemah dari plastik biodegradabel ini disebabkan karena perbedaan sifat antara pati dan plastik LDPE. Untuk mengatasi perbedaan sifat antara pati dan LDPE, perlu ditambahkan suatu bahan agen pengikat silang antara pati dan plastik LDPE. Penelitian mengenai penggunaan maleat anhidrida sebagai agen pengikat silang telah dilakukan oleh Husseinsyah et al. (2014) yang berusaha menggrafting polypropylene (PP) yang menghasilkan ikatan kimia yang baik antara plastik dengan pati.

Pati biji durian yang telah digunakan pada penelitian sebelumnya memiliki hasil yang baik dalam pencampurannya dengan limbah polipropilena. Namun, durian merupakan buah musiman yang dikhawatirkan ketersediaannya setiap saat akan terbatas pada waktu tertentu (Elda et al., 2015), sehingga diperlukan sumber pati lain yang ketersediaannya dalam jangka panjang dan sumbernya mudah didapatkan. Tandan kosong sawit merupakan limbah yang tidak memiliki nilai jual selama ini. Pemanfaatan tandan kosong sawit telah dilakukan oleh Junaidi (2015) yang memanfaatkan serat dari tandan kosong sawit menjadi papan komposit. Tandan kosong sawit memiliki kandungan pati yang tinggi yaitu sebesar $45,95 \%$ sehingga dapat digunakan sebagai sumber pati untuk plastik biodegradabel.

Berdasarkan uraian tersebut, peneliti melakukan suatu penelitian pembuatan plastik biodegradabel dengan limbah plastik polietilena (PE) jenis LDPE dan pati tandan kosong sawit (TKS) dengan penambahan maleat anhidrida sebagai agen pengikat silang, dan benzoil peroksida sebagai inisiator. Ekstraksi pati dari TKS dengan menggunakan metode perendaman dengan air, proses pencampuran pembentukan plastik biodegradabel dengan metode refluks dengan menggunakan pelarut xilena, serta proses pencetakan plastik biodegradabel dengan metode kempa tekan (hot press). Karakterisasi plastik biodegradabel yang dihasilkan dilakukan dengan beberapa analisis yaitu analisis sifat mekanik dengan uji kekuatan tarik dan uji kemuluran, analisis sifat termal dengan uji DTA dan TGA, dan analisis sifat permukaan dengan uji SEM.

\section{BAHAN DAN METODE \\ Bahan Penelitian}

Bahan yang digunakan dalam penelitian ini adalah sebagai berikut: limbah LDPE dari limbah kantong plastik buah, pelarut xilena p.a., metanol p.a., aseton p.a., benzoil peroksida p.a., maleat anhidrida p.a., tandan kosong sawit, air, dan akuades.

\section{Peralatan Penelitian}

Peralatan yang digunakan dalam penelitian ini adalah: neraca analitis dengan merek Mettler Toledo, labu refluks ukuran $500 \mathrm{~mL}$ merek Pyrex, pengaduk magnetik, alat pemanas, pengaduk merek PMC, pendingin Liebig merek Pyrex, oven listrik merek Memmert, alat cetak tekan merek Torsee SC-2DE, alat-alat gelas merek Pyrex, alat uji tarik Type SC-2DE, CAP 2000 kgf, termometer, blender merek National, ayakan 100 mesh merek Tantalum 3N8 Purity, scanning electron 
microscope (SEM) JEOL tipe JSM-6360LA, thermogravimetic analyzer (TGA) DT-30 merek Shimadzu.

\section{Metode Penelitian}

Ekstraksi pati dari tandan kosong sawit (TKS)

Tandan kosong sawit (TKS) dicuci dan dibersihkan. TKS dibelah lalu dipisahkan dari kulit kerasnya. Bagian dalam TKS dicacah dengan pisau cacah sampai ukuran sekitar 1-2 cm. Serbuk TKS direndam sambil diaduk selama 1 jam kemudian disaring. Ampas dibuang, air pati diendapkan kembali lalu disaring sehingga didapatkan pati basah. Pati TKS dipanaskan pada suhu $50^{\circ} \mathrm{C}$ selama 6 jam, kemudian diayak 100 mesh sehingga didapatkan pati TKS yang halus dan kering.

\section{Pembuatan serbuk plastik biodegradabel}

Limbah polietilena jenis LDPE yang bersumber dari limbah kemasan plastik pengemas buah di supermarket dibersihkan dan dipotong kecil dengan ukuran $0,5 \mathrm{~cm} \times 0,5 \mathrm{~cm}$ lalu dimasukkan ke dalam labu alas dan direfluks dengan pelarut xilena pada suhu $110^{\circ} \mathrm{C}$ selama 2 jam. Maleat anhidrida dan benzoil peroksida ditambahkan sesuai perbandingan dan direfluks kembali selama 30 menit, terakhir ditambahkan pati TKS sesuai perbandingan dan direfluks kembali selama 30 menit. Larutan plastik biodegradabel diendapkan dengan menggunakan metanol. Endapan dikeluarkan dan dikeringkan serta dihaluskan sehingga menjadi serbuk plastik biodegradabel lalu diayak dengan ayakan 100 mesh (Hidayani, 2015).

\section{Proses kempa tekan plastik biodegradabel}

Serbuk plastik biodegradabel dengan berbagai variasi dan komposisi massa yang telah dihasilkan (Tabel 1) dimasukkan ke dalam alat cetak tekan dan ditekan pada alat tekan hidrolik dengan tekan- an $150 \mathrm{~kg} / \mathrm{cm}^{2}$ pada temperatur $110^{\circ} \mathrm{C}$ selama 15 menit. Hasil yang diperoleh didinginkan pada suhu kamar dan dikeluarkan dari dalam cetakan.

\section{Karakterisasi sifat fisika plastik biodegradabel yang dihasilkan}

Analisis kekuatan tarik dan kemuluran dengan acuan standar ASTM D-1822 type L dengan panjang cuplikan $63,5 \mathrm{~mm}$ dan lebar 9,53 $\mathrm{mm}$. Dari variasi komposisi pengisi yang berbeda untuk menghasilkan plastik biodegradabel merupakan faktor penting untuk menentukan sifat mekanik plastik biodegradabel yang diinginkan.

Analisis termal diferensial (DTA) yang mengukur perbedaan suhu $(\mathrm{T})$, antara sampel dengan material referensi yang inert sebagai fungsi dari suhu. Keberadaan DTA dapat digunakan sebagai alat karakterisasi atau analisis material. Thermogravimetric analysis (TGA) adalah suatu teknik analisis untuk menentukan stabilitas suatu material dan fraksi komponen volatile dengan menghitung perubahan berat yang dihubungkan dengan perubahan temperatur (Vasile, 2016). Tahapan karakterisasinya adalah dengan meletakkan sampel dalam bentuk serbuk ke dalam pelat alumina. Urutan pemanasannya diprogram mulai dari $90^{\circ} \mathrm{C}$ dan ditahan selama 10 menit, kemudian pemanasan dengan cepat dilanjutkan menjadi $450^{\circ} \mathrm{C}$ kemudian suhu diturunkan menjadi $400^{\circ} \mathrm{C}$ dan ditahan selama 30 menit.

SEM adalah alat yang dapat membentuk bayangan permukaan spesimen secara mikroskopik. Berkas elektron dengan diameter 5-10 nm diarahkan pada spesimen. Interaksi berkas elektron dengan spesimen menghasilkan beberapa fenomena yaitu hamburan balik berkas elektron, sinar $\mathrm{X}$, elektron sekunder dan absorpsi elektron. Pada penelitian ini, perbesaran hasil SEM yang digunakan adalah 100x perbesaran dari keadaan awal.

Tabel 1. Perbandingan komposisi serbuk limbah LDPE, pati TKS, maleat anhidrida dan benzoil peroksida

\begin{tabular}{ccccc}
\hline No & $\begin{array}{c}\text { Serbuk limbah LDPE } \\
(\%)\end{array}$ & Pati TKS (\%) & $\begin{array}{c}\text { Maleat anhidrida (MA) } \\
(\%)\end{array}$ & $\begin{array}{c}\text { Benzoil peroksida } \\
(\text { BPO) }(\%)\end{array}$ \\
\hline 1 & 100 & 0 & 0 & 0 \\
2 & 90 & 10 & 1 & 1 \\
3 & 80 & 20 & 1 & 1 \\
4 & 70 & 30 & 1 & 1 \\
5 & 60 & 40 & 1 & 1 \\
6 & 50 & 50 & 1 & 1 \\
\hline
\end{tabular}


HASIL DAN PEMBAHASAN

\section{Analisis Sifat Mekanik dengan Uji Kuat Tarik dan Kemuluran}

Analisis kuat tarik dan kemuluran dari plastik biodegradabel yang dihasilkan dengan berbagai variasi massa dapat dilihat pada Tabel 2. Penambahan pati ke dalam plastik biodegradabel akan menurunkan nilai kekuatan tarik dan kemuluran dari plastik, hal ini terjadi karena sifat dasar plastik diubah dengan adanya bahan polimer alam yang bersifat polar. Rata-rata penambahan polimer alam ke dalam polimer sintetis akan mencapai kondisi optimum pada saat komposisi polimer sintetis yang ditambahkan di bawah 50\% (Sapuan et al., 2003).

Sifat plastik biodegradabel yang diharapkan adalah memiliki kuat tarik yang baik dan nilai kemuluran di bawah 5\% yang menunjukkan berkurangnya sifat polimer sintetis dari plastik tersebut (BSN, 2011). Dari Tabel 2 dapat dilihat bahwa karakteristik mekanik komposit plastik biodegradabel yang dihasilkan yang paling memenuhi harapan sesuai dengan nilai standar tentang plastik biodegradabel adalah plastik biodegradabel dengan perbandingan limbah LDPE, pati TKS, maleat anhidrida, benzoil peroksida (60:40:1:1) dengan harga kuat tarik $6,9410 \mathrm{~N} / \mathrm{mm}^{2}$ dan nilai kemuluran 3,1875\%. Dibandingkan dengan penggunaan polipropilena sebagai matriks plastik biodegradabel, plastik biodegradabel dengan matriks LDPE memiliki nilai kemuluran lebih baik. Plastik biodegradabel dengan matriks polipropilena memiliki nilai kemuluran sebesar 5,292\% (Hidayani et al., 2015).

\section{Analisis Sifat Termal dengan Uji DTA dan TGA}

Analisis DTA bertujuan untuk mengetahui sifat-sifat komponen plastik biodegradabel yang dihasilkan berdasarkan sifat termalnya. Analisis sifat termal dapat memberikan informasi-informasi tentang perubahan fisik plastik biodegradabel, misalnya titik leleh, terjadinya proses kimia yang mencakup polimerisasi, degradasi, dan dekomposisi. Dalam bidang campuran polimer (poliblend) pengamatan suhu transisi kaca $\left(\mathrm{T}_{\mathrm{g}}\right)$ sangat penting untuk meramalkan interaksi antara rantai dan mekanisme pencampuran beberapa polimer.

Campuran polimer yang homogen akan menunjukkan satu puncak $\mathrm{T}_{g}$ (eksotermis) yang tajam dan merupakan fungsi komposisi. $\mathrm{T}_{\mathrm{g}}$ campuran biasanya berada diantara $\mathrm{T}_{\mathrm{g}}$ dari kedua komponen, karena itu pencampuran homogen digunakan untuk menurunkan $\mathrm{T}_{\mathrm{g}}$, seperti halnya plastisasi dengan pemlastis cair. Pencampuran polimer heterogen ditujukan untuk menaikkan ketahanan bentur bahan polimer (Junaidi, 2015). Berdasarkan kondisi optimum yang telah didapatkan pada uji sifat mekanik, maka uji DTA dan TGA dilakukan terhadap plastik biodegradabel dengan perbandingan $(60: 40: 1: 1)$ dengan hasil suhu titik leburnya $103^{\circ} \mathrm{C}$ dan suhu titik terdekomposisinya $384^{\circ} \mathrm{C}$. Suhu tersebut sesuai dengan perpaduan antara suhu limbah LDPE awal dan pati TKS yang pada suhu titik lebur mengalami penurunan. Hal ini menunjukan berkurangnya sifat plastik LDPE dari $110^{\circ} \mathrm{C}$ menjadi $103^{\circ} \mathrm{C}$. Ini mengindikasikan bahwa sifat plastik LDPE masih menonjol namun telah terpengaruh bahan lain. Suhu terdekomposisi limbah LDPE adalah $320^{\circ} \mathrm{C}$ dan setelah penambahan pati mengalami kenaikan menjadi $384^{\circ} \mathrm{C}$ yang menunjukkan adanya pengaruh penambahan zat lain dalam hal ini pati yang meningkatkan ketahanan termal dan adanya interaksi langsung dari plastik biodegradabel (Hidayani et al., 2015).

TGA biasanya digunakan dalam riset untuk menentukan karakteristik material seperti polimer, penurunan temperatur, kandungan material yang diserap, komponen anorganik dan organik di dalam material, dekomposisi bahan yang mudah meledak, dan residu bahan pelarut. Pada pencampuran antara bahan polimer dari jenis polimer alam dan polimer sintetis, persentase residu atom karbon yang diharapkan lebih besar dari $10 \%$ un-

Tabel 2. Hasil perhitungan uji mekanik plastik biodegradabel.

\begin{tabular}{lccc}
\hline No & LDPE:Pati:MA:BPO & Kuat tarik $\left(\mathrm{N} / \mathrm{mm}^{2}\right)$ & Kemuluran $(\%)$ \\
\hline 1 & Limbah LDPE & 17,878 & 10,29 \\
2 & $(90: 10: 1: 1)$ & 17,586 & 9,87 \\
3 & $(80: 20: 1: 1)$ & 16,010 & 9,25 \\
4 & $(70: 30: 1: 1)$ & 10,303 & 7,62 \\
5 & $(60: 40: 1: 1)$ & 6,941 & 3,18 \\
6 & $(50: 50: 1: 1)$ & 2,436 & 8,59 \\
\hline
\end{tabular}


tuk memperlihatkan keterlibatan polimer alam dalam proses pencampuran (Astawan, 2008). Dari data TGA dapat dilihat bahwa pada limbah LDPE menghasilkan residu sebesar $0,065 \%$ sedangkan plastik biodegradabel dengan perbandingan (60:40:1:1) menghasilkan residu dalam persentase yang lebih tinggi yakni $12,6 \%$, hal ini mungkin terjadi pati TKS mengandung atom karbon organik yang paling akhir terurai (Junaidi, 2015).

\section{Analisis Sifat Morfologi dengan Uji SEM}

Hasil dari analisis SEM dapat memberikan informasi tentang bentuk dan perubahan permukaan dari limbah LDPE dan plastik biodegradabel yang dihasilkan (Nirmala et al., 2014). Pada prinsipnya bila terjadi perubahan pada suatu bahan misalnya patahan, lekukan, dan perubahan struktur maka bahan tersebut cenderung mengalami perubahan energi. Energi yang berubah tersebut dapat dipancarkan, dipantulkan, dan diserap serta diubah menjadi gelombang elektron yang dapat di tang-

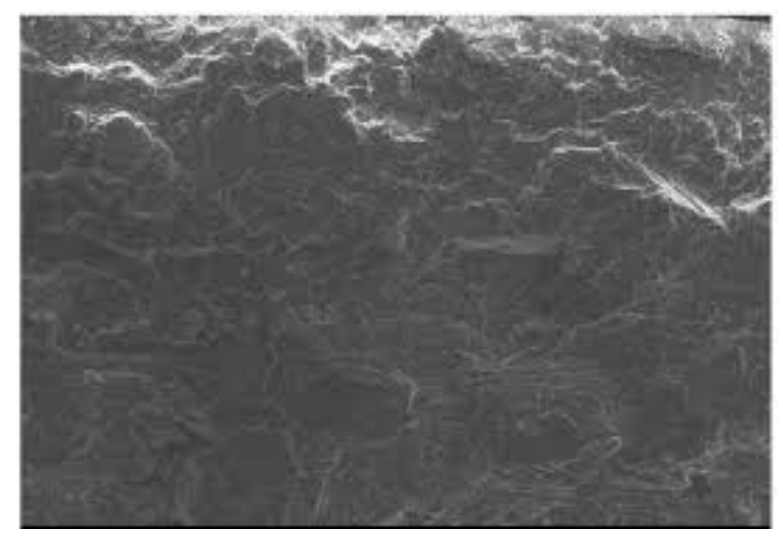

Gambar 1. Hasil SEM Limbah LDPE dengan perbesaran 100x.

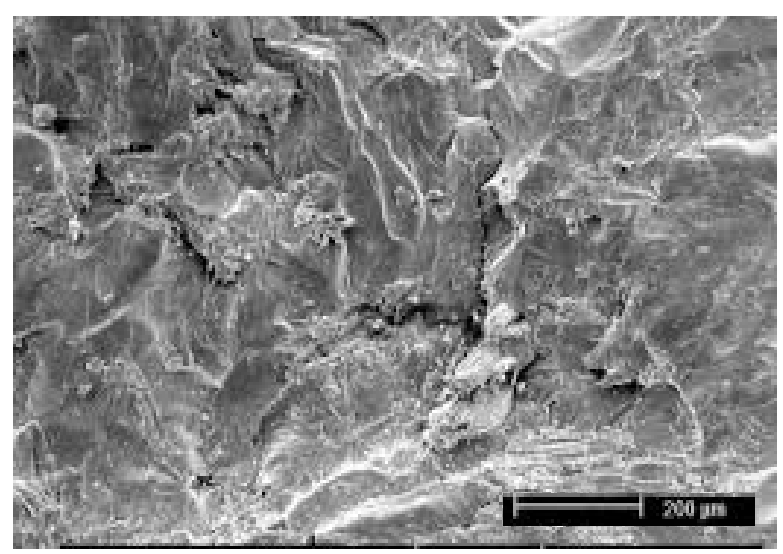

Gambar 2. Hasil SEM plastik biodegradabel dengan perbandingan (60:40:1:1) dengan perbesaran 100x. kap dan dibaca hasilnya pada foto SEM.

Hasil uji SEM terlihat pada Gambar 1 dan 2. Dari Gambar 2 terlihat permukaan plastik biodegradabel yang dihasilkan pada perbandingan (60:40:1:1) terdapat pori yang tersebar merata. Dalam hal ini, pori yang terlihat tersebut berasal dari pati TKS dan maleat anhidrida yang ditambahkan pada limbah LDPE. Dari gambar hasil SEM dapat dilihat bahwa pati TKS yang ditambahkan tersebar secara merata pada permukaan plastik biodegradabel yang dihasilkan. Interaksi yang terjadi keduanya merupakan interaksi kimia dan fisika yaitu pencampuran dua bahan dan interaksi kimia yaitu terjadinya ikatan struktur antara limbah LDPE-g-MA dan pati TKS.

\section{KESIMPULAN}

Plastik biodegradabel dapat dihasilkan dari pencampuran limbah LDPE dan pati TKS dengan bantuan benzoil peroksida sebagai inisiator dan maleat anhidrida sebagai agen pengikat silang antara plastik dan pati. Kondisi optimum dari plastik biodegradabel yang dihasilkan adalah pada perbandingan limbah LDPE : pati TKS : maleat anhidrida : benzoil peroksida sebesar 60:40:1:1. Komposisi pati yang mencapai $40 \%$ akan mempercepat proses biodegradasi karena pati dapat diuraikan di alam.

Plastik biodegradabel dengan perbandingan limbah LDPE, pati TKS, maleat anhidrida, benzoil peroksida (60:40:1:1) memiliki harga kuat tarik $6,9410 \mathrm{~N} / \mathrm{m}^{2}$ dan nilai kemuluran 3,1875\%, suhu titik lebur $103^{\circ} \mathrm{C}$ dan suhu terdekomposisi $384^{\circ} \mathrm{C}$, pada uji termal gravimetri didapatkan residu $12,6 \%$, dan analisis sifat morfologi menunjukkan sebaran pati TKS merata pada limbah plastik LDPE dengan bantuan maleat anhidrida dan benzoil peroksida.

\section{UCAPAN TERIMA KASIH}

Penulis mengucapkan terima kasih kepada semua fihak yang telah membantu terselesaikannya penelitian dan karya tulis ilmiah ini.

\section{DAFTAR PUSTAKA}

Astawan, A. (2008). Komposit: Pengaman dan pengawet makanan. Jakarta, Indonesia: Senior.

BSN (Badan Standardisasi Nasional). (2011). Standard Nasional Indonesia SNI 7188.7:2011: Kriteria ekolabel-bagian 7: Kategori produk kantong belanja plastik. Jakarta, Indonesia: BSN.

Elda, P., Nirmala, D. \& Hidayani, R. (2015). Pengaruh penambahan maleat anhidrida dan benzoil 
peroksida sebagai agen pengikat silang pada plastik biodegradabel dari limbah polipropilena dengan bahan pengisi pati biji durian (Laporan Hasil Penelitian). Politeknik ATI Padang, Indonesia.

Hidayani, T. R., Pelita, E., Nirmala, D. (2015). Karakteristik plastik biodegradabel dari limbah plastik polipropilena dan pati biji durian hasil ekstraksi dengan variasi komposisi massa. Majalah Kulit, Karet, dan Plastik, 31(1), 15-21, https://doi.org/10.20543/mkkp.v31i1.178

Husseinsyah, S., Marliza, M. Z., \& Selvi, E. (2014). Biocomposites from polypropylene and corn cob: Effect maleic anhydride grafted polypropylene. Advances in Materials Research, 3(3), 129-137.

Inggaweni, L. (2015). Karakterisasi sifat mekanik plastik biodegradable dari komposit high density polyethylene (HDPE) dan pati kulit singkong. Dalam Seminar Nasional Kimia. Surabaya, Indonesia: Universitas Negeri Surabaya.

Junaidi. (2015). Pengembangan papan komposit dari serat tandan kosong sawit (TKS) berperekat gambir berlapis anyaman bambu (Disertasi). Politeknik Negeri Padang, Indonesia.

Khoramnejadian, S., Zavareh, J. J., \& Khoramnejadian, S. (2013). Effect of potato starch on thermal \& mechanical properties of low density polyethylene. Current World Environment. 8(2), 215-220, https://doi.org/10.12944/CWE.8.2.06
Matondang, T.D. S. (2013). Interaksi kimia dari pati sagu kelapa sawit sebagai pengisi pada poliprpopilena tergrafting anhidrida maleat dalam pembuatan bahan plastik kemasan terbiodegradasikan. Jurnal Natur Indonesia, 2(06).

Nirmala, D. Hidayani, T. R., \& Pelita, E. (2014). Interaksi fisika plastik biodegradabel dari limbah polipropilena dengan bahan pengisi pati biji durian (Laporan Penelitian). ATIP, Indonesia.

Sapuan, S. M., Harimi, M., \& Maleque, M. A. (2003). Mechanical properties of epoxy/coconut shell filler particle composites. The Arabian Journal for Science and Engineering. 28(2B), 173-181.

Susilawati, S., Mustafa, I., \& Maulina, D. (2011). Biodegradable plastics from a mixture of LDPE and cassava starch with addition of acrylic acid. Jurnal Natural, 11(02), 69-73.

Vasile, C. (2016). Gamma irradiation assisted fungal degradation of the polypropylene/biomass composites. Polymer Composite, 2, 762-768. 